\section{Nutrient Release from Controlled- release Fertilizers in Acid Substrate in a Greenhouse Environment: I. Leachate Electrical Conductivity, pH, and Nitrogen, Phosphorus, and Potassium Concentrations}

\author{
Donald J. Merhaut, Eugene K. Blythe \\ University of California, Riverside, Botany and Plant Sciences, 4118 Batchelor \\ Hall, Riverside CA 92521
}

Julie P. Newman

University of California, 669 County Square Drive, Suite 100, Ventura, CA 93003

Joseph P. Albano

U.S. Horticultural Laboratory, U.S. Department of Agriculture, Agricultural Research Service, 2001 S. Rock Road, Ft. Pierce, FL 34945

Additional index words. nitrate, ortho-phosphate, nursery, Nutricote, Osmocote, Polyon, Multicote, polymers, macronutrients, potassium, ammonium, nitrogen, phosphorus

\begin{abstract}
Release characteristics of four types of controlled-release fertilizers (Osmocote, Nutricote, Polyon, and Multicote) were studied during a 47-week simulated plant production cycle. The 2.4-L containers containing a low-fertility, acid-based substrate were placed in an unheated greenhouse and subjected to environmental conditions often used for production of azaleas and camellias. Leachate from containers was collected weekly and monitored for $\mathrm{pH}$, electrical conductivity, and concentrations of $\mathrm{NH}_{4}^{+} \mathrm{N}, \mathrm{NO}_{3}^{-} \mathrm{N}$, total $\mathrm{P}$ and total $\mathrm{K}$. Leachate concentrations of all nutrients were relatively high during the first 10 to 20 weeks of the study, and then gradually decreased during the remaining portion of the experiment. Differences were observed among fertilizer types, with Multicote often resulting in higher concentrations of $N, P$, and $K$ in leachates compared to the leachates from the other fertilizer types during the first half of the study. Concentrations of $\mathrm{NO}_{3}^{-}$and $\mathrm{P}$ from all fertilizer types were often above permissible levels as cited in the federal Clean Water Act.
\end{abstract}

The Federal Water Pollution Control Act of 1948 was overhauled in 1972 with the addition of several amendments that directed regulations towards nonpoint sources of pollution, including commercial and private landscapes and nurseries. Since that time, the Act has been referred to as the Clean Water Act and, among other items, requires that all states must identify impaired waterbodies in their region and must implement regulations to mitigate pollutant runoff from any point and nonpoint sources. States are to use the U.S. Environmental Protection Agency (EPA) set of guidelines referred to as the Total Maximum Daily Loads (TMDLs) process described in

Received for publication 10 Nov. 2005. Accepted for publication 8 Jan. 2006. This research was funded in part by grants from the Hansen Trust Fund and the California Department of Food and Agriculture-Fertilizer and Research and Education Program(CDFA-FREP). Trade names are mentioned throughout this manuscript, but this does not imply product endorsement by the authors and their associated institutions. Special thanks are given to Shahram Ahmadian and Harold D. Ewing for their technical assistance.

${ }^{1}$ To whom reprint requests should be addressed; e-mail donald.merhaut@ucr.edu.
(Goertz, 1993). Most of the research related to nutrient release characteristics from CRFs have been undertaken using atypical substrates such as $100 \%$ sand, under controlled laboratory conditions (Broschat, 1996; 2005; Handreck, 1997; Havis and Baker, 1985a; Holcomb, 1981; Huett and Gogel, 2000; Husby et al., 2003; Lamont et al., 1987; Lunt and Oertli, 1962; Oertli and Lunt, 1962; Patel and Sharma, 1977), or by means of field studies (Gandeza et al., 1991), none of which reflects conditions experienced in container-production facilities. In addition, the duration of many experiments has been limited to $\leq 6$ months, which is insufficient for measuring nutrient release from 12-monthrelease fertilizer formulations, as alluded to by Havis and Baker (1985a). The following study quantifies the nutrient release patterns of four types of CRFs, when blended into an acid substrate during an 11-month period in an unheated greenhouse environment, a production scenario often used for ericaceous crops such as azaleas and rhododendrons. Plants were not included in the study so that nutrient release characteristics could be easily monitored through leaching characteristics, without the influence of nutrient uptake into plants.

\section{Materials and Methods}

Substrate. Substrate consisted of a mixture of 5 sphagnum peatmoss (Premier Horticulture Inc., Red Hill, Pa.) : 4 pine bark (6.4 to 9.5 $\mathrm{mm})$ : 1 washed builder's sand (by volume). The substrate was amended with dolomite 65 (Chemical Lime Co., Scottsdale, Ariz.) at a rate of $0.59 \mathrm{~kg} \cdot \mathrm{m}^{-3}$ and ultrafine calcium sulfate (Western Mining and Minerals, Apex, $\mathrm{Nev}$.) at a rate of $0.59 \mathrm{~kg} \cdot \mathrm{m}^{-3}$. Substrate and amendments were blended together using a batch mixer (model MB20L5; Measured Marketing, Kankakee, Ill.). Substrate $\mathrm{pH}$ was 4.5 at the initiation of the experiment. For nutrient analyses, media were air-dried and ground to $0.420 \mathrm{~mm}$ with a Wiley Mill (model \#3; Arthur H. Thomas Co., Philadelphia). The ground samples were extracted using the 1:2 dilution method as described by Lang (1996), where $50 \mathrm{~mL}$ volume of ground substrate was diluted with $100 \mathrm{~mL}$ deionized water, mixed, allowed to equilibrate for $30 \mathrm{~min}$, and gravity filtered through Whatman 41 filter paper (Whatman Int., Ltd., Maidstone, England). Total $\mathrm{P}$ and $\mathrm{K}$ concentrations in extracts were quantitatively determined using an inductively coupled plasma-optical emission spectrometer (ICP-OES) (Thermo Electron Corp., model IRIS 1000 HR, Franklin, Mass.). Total N of the substrate was quantitatively determined by combustion on a $\mathrm{N}$ gas analyzer (LECOFP528; Leco Corp., St. Joseph, Mich.) (Sweeney, 1989). Nutrient concentrations prior to incorporation of CRFs were as follows: $0.12 \%$ total $\mathrm{N}, 0.01 \%$ extractable $\mathrm{P}$, and $0.02 \%$ extractable $\mathrm{K}$.

Fertilizer treatments. Treatments consisted of four different CRFs: Osmocote 24-4-9 (Scott-Sierra Horticultural Products Co., Marysville, Ohio), Nutricote 18-6-8 Total (Chisso-Asahi Fertilizer Co., Tokyo), Multicote 17-5-11 + minors (Haifa Chemicals, 
Table 1. Sources and amount (\% by weight) of nitrogen $(\mathrm{N})$, phosphorus $(\mathrm{P})$, and potassium $(\mathrm{K})$ in Osmocote 24-4-9, Polyon 17-5-11 + micros, Multicote 17-5-11 + minors, and Nutricote 18-6-8 total.

\begin{tabular}{lcccccc}
\hline Fertilizer type & $\mathrm{NH}_{4}^{+} \mathrm{N}$ & $\mathrm{NO}_{3}^{-} \mathrm{N}$ & Urea N & Total N & $\mathrm{P}$ & $\mathrm{K}$ \\
\hline Osmocote $^{\mathrm{z}}$ & 6.40 & 5.70 & 11.90 & 24.00 & 1.68 & 7.44 \\
Polyon $^{\mathrm{y}}$ & 7.30 & 9.70 & 0.00 & 17.00 & 2.02 & 8.85 \\
Multicote $^{\mathrm{x}}$ & 9.00 & 8.00 & 0.00 & 17.00 & 2.10 & 9.10 \\
Nutricote $^{\mathrm{w}}$ & 8.60 & 9.40 & 0.00 & 18.00 & 2.52 & 6.62
\end{tabular}

${ }^{\mathrm{z}}$ Osmocote 24-4-9. Nitrogen, phosphorus, and potassium are derived from ammonium nitrate, ammonium phosphate, polymer-encapsulated sulfur coated urea, calcium phosphate, and potassium sulfate.

yPolyon 17-5-11. Nitrogen, phosphorus, and potassium are derived from ammonium nitrate, ammonium phosphate, potassium sulfate, and potassium nitrate.

${ }^{x}$ Multicote 17-5-11 + minors. Nitrogen, phosphorus, and potassium are derived from ammonium nitrate, mono ammonium phosphate, potassium nitrate, and potassium sulfate.

"Nutricote 18-6-8 total. Nitrogen, phosphorus, and potassium are derived from ammonium nitrate, ammonium phosphate, calcium phosphate, and potassium nitrate.

Table 2. Amount ( $\mathrm{g}$ ) of nitrogen $(\mathrm{N})$, phosphorus $(\mathrm{P})$, and potassium $(\mathrm{K})$ incorporated into each \#1 container $(2.4 \mathrm{~L})$ of substrate. Fertilizer rates were normalized for the same amount of nitrogen ( $3.11 \mathrm{~g} / \# 1$ container $)$ since different brands of fertilizers contained different ratios of nutrients.

\begin{tabular}{lcccccc}
\hline Treatment (fertilizer) & $\mathrm{NH}_{4}^{+} \mathrm{N}$ & $\mathrm{NO}_{3}^{-} \mathrm{N}$ & Urea N & Total $\mathrm{N}$ & $\mathrm{P}$ & $\mathrm{K}$ \\
\hline Osmocote & 0.83 & 0.74 & 1.54 & 3.11 & 0.22 & 0.96 \\
Polyon & 1.65 & 1.46 & 0.00 & 3.11 & 0.37 & 1.62 \\
Multicote & 1.65 & 1.46 & 0.00 & 3.11 & 0.38 & 1.66 \\
Nutricote & 1.49 & 1.62 & 0.00 & 3.11 & 0.44 & 1.14 \\
\hline
\end{tabular}

Ltd., Haifa Bay, Israel), and Polyon 17-5-11+ micros (Pursell Technologies, Inc., Sylacauga, Ala.). All four fertilizers release nutrients based on water diffusion into prills, the rate of which is regulated by temperature. Osmocote did not contain micronutrients; therefore, micronutrients were provided by incorporation of Micromax (Scott-Sierra Horticultural Products Co., Marysville, Ohio), an uncoated, granular fertilizer at a rate of $0.53 \mathrm{~kg} \cdot \mathrm{m}^{-3}$. All CRFs were 365-d release formulations; however, release rates of these CRFs are based on different temperature regimes: $27{ }^{\circ} \mathrm{C}$ for Osmocote and Polyon, $21^{\circ} \mathrm{C}$ for Multicote, and 21 to $27^{\circ} \mathrm{C}$ for Nutricote. Element concentrations and compounds used in each fertilizer were different (Table 1). Since the percentage of nutrients contained in the different fertilizers varied, the amount of fertilizer added was calculated so that all treatments contained 3.11 $\mathrm{g} \mathrm{N} /$ container, which is equivalent to $1.17 \mathrm{~kg}$ $\mathrm{N} / \mathrm{m}^{3}$, an average rate which the four fertilizer manufacturers recommended for slow-growing woody ornamentals. While $\mathrm{N}$ content for all CRF treatments was the same, the content of other nutrients varied (Table 2). CRF prills were incorporated throughout the substrate using a portable cement mixer. Substrate with CRF was placed in \#1 black polyethylene containers $(2.4 \mathrm{~L} ; 157 \mathrm{~mm}$ top diameter, 127 $\mathrm{mm}$ bottom diameter, $178 \mathrm{~mm}$ tall; Farrand Enterprises, Chino, Calif.) with side and bottom drainage holes. Each container represented one replication. There were five replications of each treatment for each of 11 months of leachate monitoring. Containers were placed in a randomized complete block design.

Cultural practices. Substrate and fertilizer treatments were prepared on 1 Aug. 2001. The experiment was conducted from 1 Aug. 2001 through 27 June 2002. Containers were placed in an unheated, poly-covered greenhouse on the University of California, Riverside campus (lat. $33^{\circ} 53^{\prime} 30^{\prime} \mathrm{N}$, long. $117^{\circ} 15^{\prime} 00^{\prime} \mathrm{W}$ ). Summer high temperatures were moderated with the use of an evaporative pad and fan cooling system, which was set to turn on at $30^{\circ} \mathrm{C}$. Winter low temperatures were moderated through the protection provided by the polyethylene cover. From 1 Aug. 2001 to 29 Oct. 2001 and 8 Apr. 2002 to 27 June 2002, the greenhouse was covered with an aluminum-coated polyester OLS50 screen (AB Ludvig Svensson, Kinna, Sweden), which provided $49 \%$ shade. Containers were irrigated with municipal tap water which contained an average of $\left(\mathrm{mg} \cdot \mathrm{L}^{-1}\right): 0.05$ $\mathrm{NH}_{4}^{+} \mathrm{N}, 2.32 \mathrm{NO}_{3}^{-} \mathrm{N}, 0.02 \mathrm{P}$, and $2.94 \mathrm{~K}$, and had a $\mathrm{pH}$ range of 7.31 to 8.50 and an EC ranging from 0.31 to $0.65 \mathrm{mS} \cdot \mathrm{cm}^{-1}$. Irrigation water was distributed uniformly over the surface of the substrate using DRT4-36 ring drippers (Dramm Corporation, Manitowoc, Wis.) made of 6.35 -mm-diameter polyethylene tubing with six drip holes spaced every $2 \mathrm{~cm}$. Containers were irrigated about every $2 \mathrm{~d}$, providing an average irrigation volume of about $1 \mathrm{~L} /$ week and an average leachate volume of about 750 water requirement of an adjacent azalea crop being grown during the same time period in the same greenhouse.

Leachate collection. Leachate was collected from each container by placing a plastic sleeve (140 $\mathrm{mm}$ bottom diameter and $165 \mathrm{~mm}$ top diameter) over each container; each container and sleeve were placed into a plastic $2.45 \mathrm{~L}$ (152 $\mathrm{mm}$ top diameter, $127 \mathrm{~mm}$ bottom diameter, and $152 \mathrm{~mm}$ high) bucket. The larger dimensions of the container compared to the collection bucket allowed the containers to be elevated above the level of the leachate. Leachate was collected from buckets twice per week, and volumes from each bucket were combined so that there was one leachate sample per container per week. Leachate electrical conductivity (EC) and $\mathrm{pH}$ were measured once per week after the first irrigation of the week. EC was measured with a Horiba conductivity meter (model B-173; Horiba Ltd., Minami-ku Kyoto, Japan), and $\mathrm{pH}$ was measured with a Horiba compact $\mathrm{pH}$ meter (model B-213; Horiba Ltd.). Immediately following EC and $\mathrm{pH}$ measurements, $2 \mathrm{~mL}$ of $2 \mathrm{~N}$ sulfuric acid were added to each bucket to chemically sta$\mathrm{mL} /$ week. This irrigation program mirrored the bilize the leachate. An additional $2 \mathrm{~mL}$ of $2 \mathrm{~N}$ sulfuric acid was then added to the emptied bucket, so that subsequent leachate collected from the container during the final part of the week was immediately stabilized. Leachate from the first collection of the week was stored at $4{ }^{\circ} \mathrm{C}$ until the end of the week, at which time leachate from the remainder of the week was added to the weekly sample. At the end of each week, collection buckets were washed with $10 \%$ bleach to prevent algal growth.

Leachate analysis. Total leachate volume from each container was measured at the end of each week. A 70-mL aliquot was taken and frozen until analysis. Solutions were analyzed for ammonium $\left(\mathrm{NH}_{4}^{+}\right) \mathrm{N}$ and $\mathrm{NO}_{3}^{-} \mathrm{N}$ with a Technicon TRAAC 800 Autoanalyzer (Technicon Instruments Corp., Tarrytown, N.Y.). Total $\mathrm{P}$ and $\mathrm{K}$ were determined using an inductively coupled plasma optical emission spectrometer (ICP-OES) (Thermo Electron Corp., model IRIS 1000 HR, Franklin, Mass.).

Statistical analysis. Preliminary analysis of the data was conducted by regressing each of the dependent variables (EC, $\mathrm{pH}$, and concentrations of individual nutrients) against time (weeks), along with the qualitative treatment and blocking factors, using a general linear model (PROC GLM). Preliminary results (not presented) indicated strong interaction between time and treatments, along with higher-level polynomial terms for the regression component of the model. To facilitate a useful interpretation of the experimental results, data were subsequently analyzed by modeling the dependent variables against only the qualitative treatment and blocking factors, with separate analyses for each week, permitting comparisons among CRF treatments at specific times during the 11-month period. Multiple comparisons among CRF treatments within a specific week were made using Tukey's Studentized range test with an experimentwise $\alpha$-level of 0.10 covering all six simultaneous pairwise comparisons. Statistical analyses were conducted using SAS Version 9.1 (SAS Institute, Cary, N.C.).

\section{Results and Discussion}

Air temperature. Weekly average greenhouse air temperature ranged between 24 and $30{ }^{\circ} \mathrm{C}$ during the first 10 weeks (August through September 2001) and the last 10 weeks (May 2002 through June 2002) of the study (Fig. 1). Maximum air temperatures during this time period ranged from 28 to 46 ${ }^{\circ} \mathrm{C}$, which are temperatures observed in other warm-temperate and subtropical growing regions (Ingram, 1981; Lamont et al., 1987). These temperatures were consistently above $21^{\circ} \mathrm{C}$, the labeled substrate temperature rating for 1-year longevity for Multicote. However, only weekly maximum air temperatures were typically above the average labeled media temperature ratings of $24{ }^{\circ} \mathrm{C}$ for Nutricote and $27^{\circ} \mathrm{C}$ for Osmocote and Polyon. Since nutrient release from many CRFs, including those in the present study, is temperature dependent, any elevated temperatures that may occur can greatly impact nutrient release characteristics of CRFs. In studies related to 


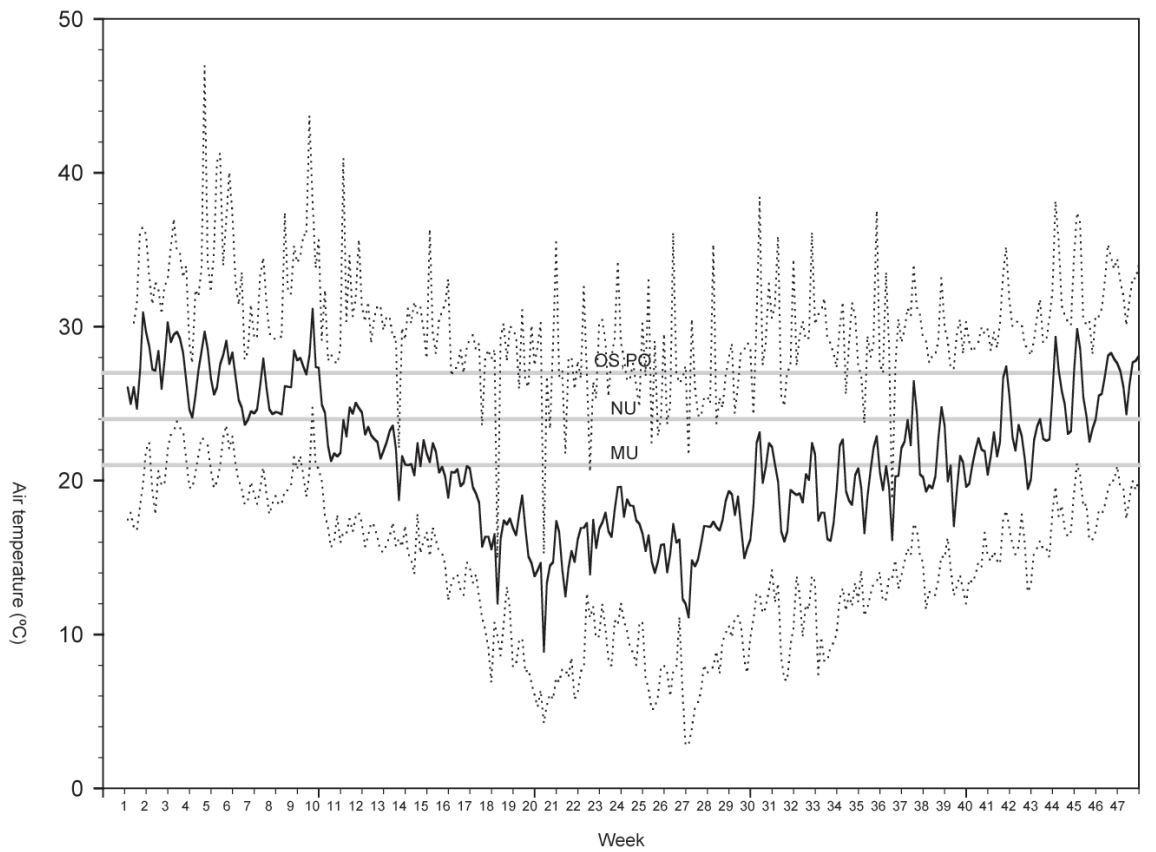

Fig. 1. Daily average (solid line), minimum (lower dotted line) and maximum (upper dotted line) greenhouse air temperatures over a 47-week period ( 1 Aug. 2001 to 27 June 2002), with gray horizontal lines indicating media temperatures for 12-month fertilizer release as specified by the respective manufacturers of Osmocote (OS), Polyon (PO), Multicote (MU), and Nutricote (NU).

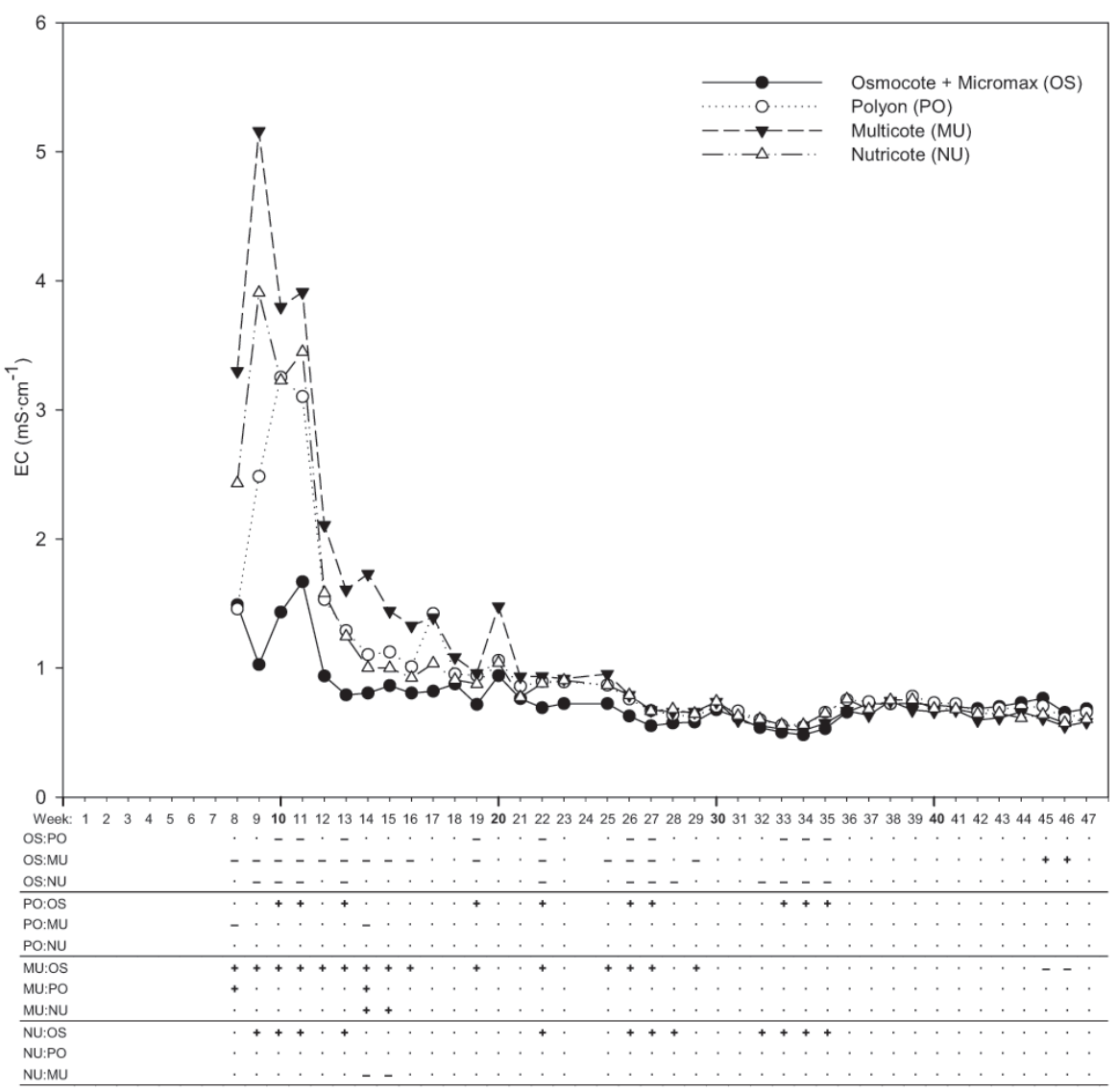

Fig. 2. Electrical conductivity (EC) of irrigation leachate collected weekly over a 47-week period (1 Aug. 2001 to 27 June 2002) from a pine bark and peat-based substrate prepared with four controlled-release fertilizers at equal rates of total $\mathrm{N}$. One-gallon containers containing substrate without plants were located in a controlled-environment greenhouse during the experiment and irrigated with drip emitters using municipal tap water $\left(\mathrm{EC} 0.5 \mathrm{mS} \cdot \mathrm{cm}^{-1}\right)$. Plotted points (top) represent least squares means for each fertilizer. Significant differences in least squares means for pairs of treatments for each week (bottom) are indicated with the first treatment listed in each pair being greater than $(+)$, less than $(-)$, or not different from $(\bullet)$ the second treatment listed in each pair according to Tukey's test $(P \leq 0.10)$. environmental conditions and CRFs, nutrient release rates increased by up to $200 \%$ for every $10{ }^{\circ} \mathrm{C}$ increase in media temperature above optimum release temperature (Husby et al., 2003; Kochba et al., 1990; Lamont et al., 1987; Oertli and Lunt, 1962); however, other experiments (Huett and Gogel, 2000) showed only a $15 \%$ increase in release rates at higher media temperatures. At suboptimum temperatures, nutrient release characteristics have been shown to be inconsistent (Engelsjord et al., 1997); however, others (Kochba et al., 1990) have shown that the nutrient release rates are lower, but uniform.

Electrical conductivity. Leachate electrical conductivity (EC) was elevated during the first 5 months of the study, relative to the later time frame, regardless of fertilizer type, with significant differences observed among treatments (Fig. 2). Similar trends in EC fluctuations have also been observed in other studies (Lamont et al., 1987). During the entire study, the leachate EC of the Osmocote treatment was often significantly lower than the EC from the other treatments, especially Multicote. Both Polyon and Nutricote treatments also had leachate EC levels that were significantly lower than levels recorded for Multicote. Near the end of the study, (weeks 45 and 46), the leachate EC for Osmocote was significantly greater than the EC for Multicote. In diurnal studies (20 h) that compared Osmocote, Nutricote, and Polyon, Osmocote resulted in leachates with lower soluble salts than Nutricote or Polyon at temperatures between 20 and $25^{\circ} \mathrm{C}$; however, Osmocote had higher release rates at temperatures above $35^{\circ} \mathrm{C}$ (Husby et al., 2003). In longer-term studies (Lamont et al., 1987), Osmocote exhibited higher release rates than Nutricote at all temperature regimes studied (5, $10,15,20,25,30,35,40$, and $\left.45^{\circ} \mathrm{C}\right)$. Based on the present study and research by Husby et al. (2003) and Lamont et al. (1987), there are daily as well as weekly trends in nutrient release from CRFs which, in the case of diurnal fluctuations, closely reflect changes in temperature. However, over extended periods of time, the pool of nutrients remaining in the prills diminishes, which results in decreased quantities of nutrient release and thus decreased EC levels, even with increased temperatures during later parts of a production period.

From an environmental perspective, federal guidelines dictate that soluble salts should not exceed $250 \mathrm{mg} \cdot \mathrm{L}^{-1}$, based on chloride and sulfate concentrations only. Therefore, monitoring and control of $\mathrm{EC}$, from a regulatory point-of-view, would be irrelevant, since EC takes into account all dissolved salts.

$p H$. During the first 20 weeks, leachate $\mathrm{pH}$ was variable, but consistently acidic (Fig. 3 ), even though irrigation water $\mathrm{pH}$ was 7.5 , indicating that substrate and/or fertilizers used in the study influenced leachate $\mathrm{pH}$ more so than did the neutral irrigation water. Other studies (Chen et al., 2003) have demonstrated that a similar substrate containing pine bark, sand, and peat buffered irrigation water of $\mathrm{pH} 9.7$ (with low alkalinity) to a measured substrate $\mathrm{pH}$ of about 6.5. In addition, a study by Ivy et al. (2002) showed that fertilizer type(Osmocote 
Fig. 3. The pH of irrigation leachate collected weekly over a 47-week period (1 Aug. 2001 to 27 June 2002) from a pine bark and peat-based substrate prepared with four controlled-release fertilizers at equal rates of total N. Plotted points (top) represent least squares means for each fertilizer. Significant differences in least squares means for pairs of treatments for each week (bottom) is indicated with the first treatment listed in each pair being greater than $(+)$, less than $(-)$, or not different from $(\bullet)$ the second treatment listed in each pair according to Tukey's test $(P \leq 0.10)$. One-gallon containers containing substrate without plants were located in a controlledenvironment greenhouse during the experiment and irrigated with drip emitters using municipal tap water (pH 7.5).

and Polyon) used does not influence $\mathrm{pH}$.

Among fertilizer types, few significant differences were detected. Leachate $\mathrm{pH}$ from substrate containing Osmocote was higher compared to the leachate $\mathrm{pH}$ of Multicote and Nutricote treatments, 2 and 4 weeks, respectively, during the 47 -week period. The $\mathrm{pH}$ readings in weeks 42 and 43 for Multicote and week 42 for Nutricote were significantly higher than the leachate $\mathrm{pH}$ for Osmocote. However, another study (Ivy et al., 2002) showed that fertilizer type (Osmocote and Polyon) did not influence $\mathrm{pH}$ but, in a different study (Argo and Biernbaum, 1997), it was determined that leachate $\mathrm{pH}$ is influenced by compounds used in fertilizers, especially in respect to the ratios of $\mathrm{NH}_{4}^{+}$to $\mathrm{NO}_{3}^{-}$, with $\mathrm{pH}$ decreasing when the amount of $\mathrm{NH}_{4}^{+}$relative to $\mathrm{NO}_{3}^{-}$increases. In the present study, the amount of $\mathrm{N}$ as $\mathrm{NH}_{4}^{+}$ ranged between $43 \%$ and $53 \%$, except for the Osmocote formulation that contained $76 \%$ of the $\mathrm{N}$ in the ammoniacal form $\left(\mathrm{NH}_{4}^{+}\right.$and urea). These differences in $\mathrm{N}$ form may not have been different enough to cause significant changes in leachate $\mathrm{pH}$ among different fertilizer treatments. None of the changes in $\mathrm{pH}$ measured in the present study fell outside the critical ranges established by the U.S. EPA ( $\mathrm{pH}$ of 5.0 to 9.0 for domestic water supplies, 6.5 to 8.5 for freshwater aquatic life, and 6.5 to 9.0 for marine aquatic life) (U.S. EPA, 1976).

Ammoniacal-nitrogen concentration. During the first 4 weeks of the study, $\mathrm{NH}_{4}^{+} \mathrm{N}$ concentrations in leachates in all treatments were below $10 \mathrm{mg} \cdot \mathrm{L}^{-1}$ (Fig. 4). From week 5 to week 9 , concentrations increased to above 150 $\mathrm{mg} \cdot \mathrm{L}^{-1}$, followed by a decline from week 10 to week 30. During the last 17 weeks, leachate

Fig. 4. Concentration of $\mathrm{NH}_{4}^{+} \mathrm{N}\left(\mathrm{mg} \cdot \mathrm{L}^{-1}\right)$ in irrigation leachate collected weekly over a 47-week period (1 Aug. 2001 to 27 June 2002) from a pine bark and peat-based substrate prepared with four controlled-release fertilizers at equal rates of total N. Plotted points (top) represent least squares means for each fertilizer. Significant differences in least squares means for pairs of treatments for each week (bottom) is indicated with the first treatment listed in each pair being greater than $(+)$, less than $(-)$, or not different from $(\bullet)$ the second treatment listed in each pair according to Tukey's test $(P \leq 0.10)$. One-gallon containers containing substrate without plants were located in a controlled-environment greenhouse during the experiment and irrigated with drip emitters using municipal tap water.

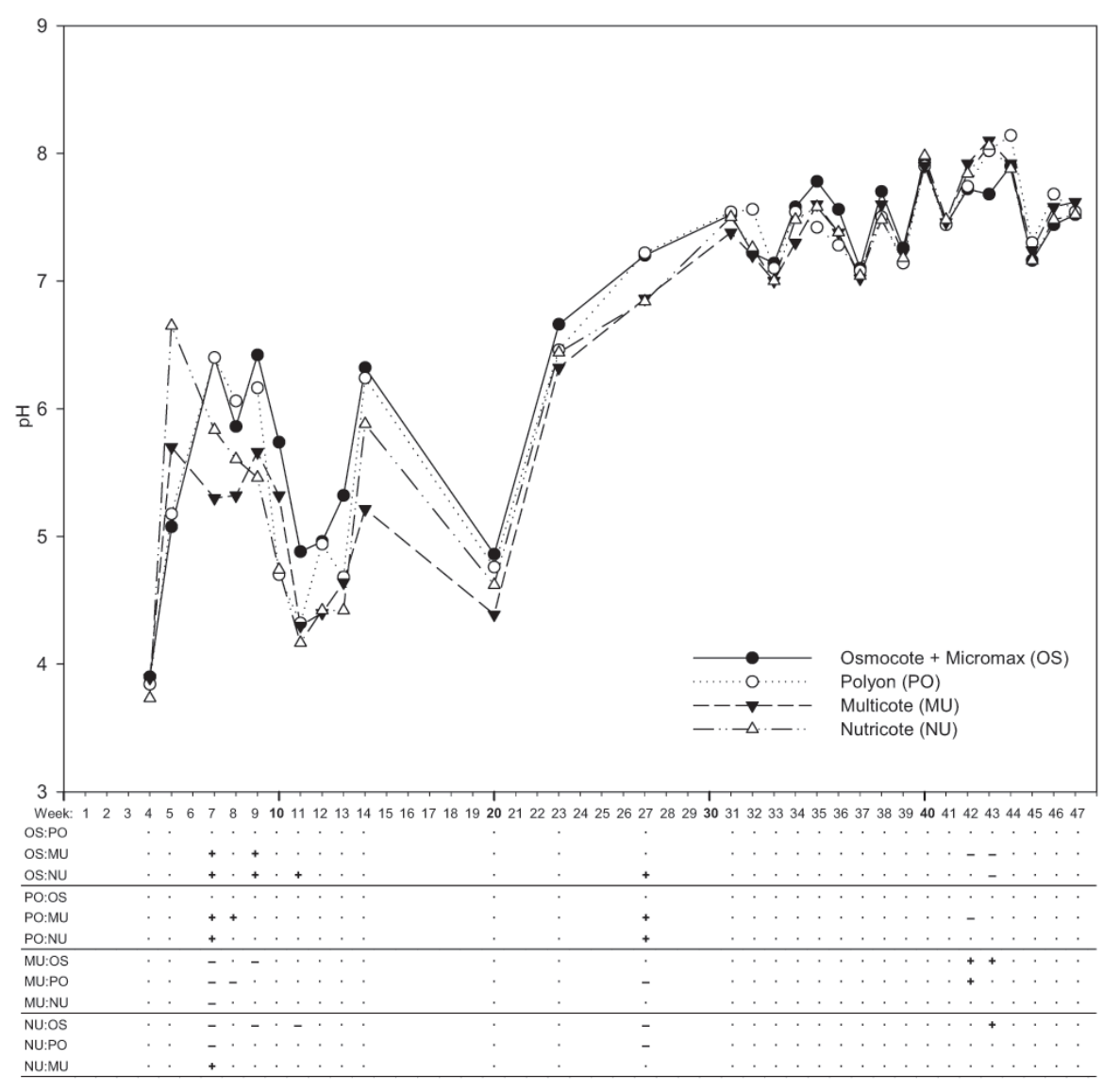

$\mathrm{NH}_{4}^{+} \mathrm{N}$ concentrations were $<1 \mathrm{mg} \cdot \mathrm{L}^{-1}$, except for the Osmocote treatment, which averaged about $3.0 \mathrm{mg}$ during the last 3 weeks of the study, which was significantly greater than with

the other fertilizer treatments. When making comparisons among treatments, leachate $\mathrm{NH}_{4}^{+}$ $\mathrm{N}$ from the Multicote treatment was significantly greater than with the other treatments

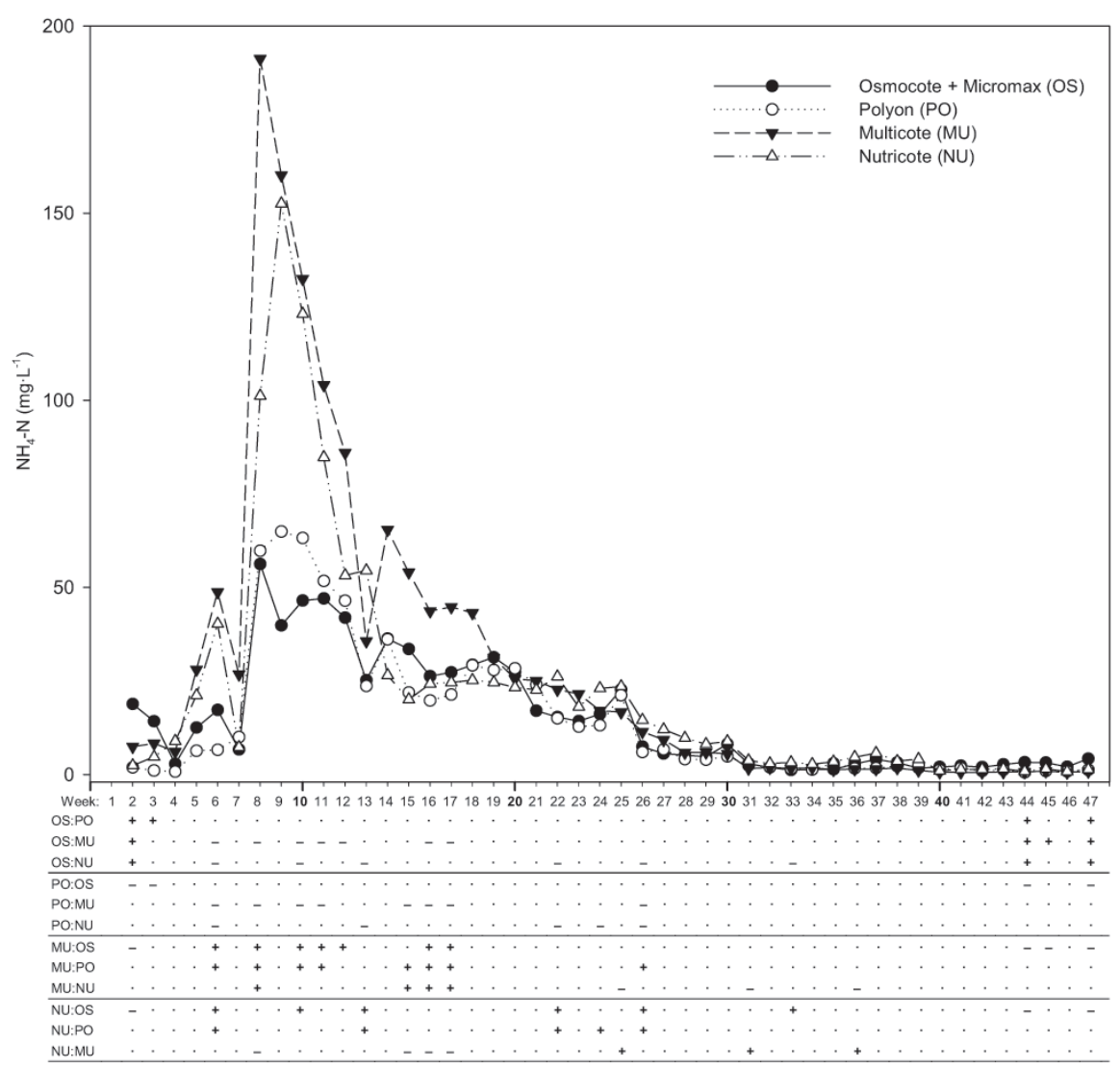




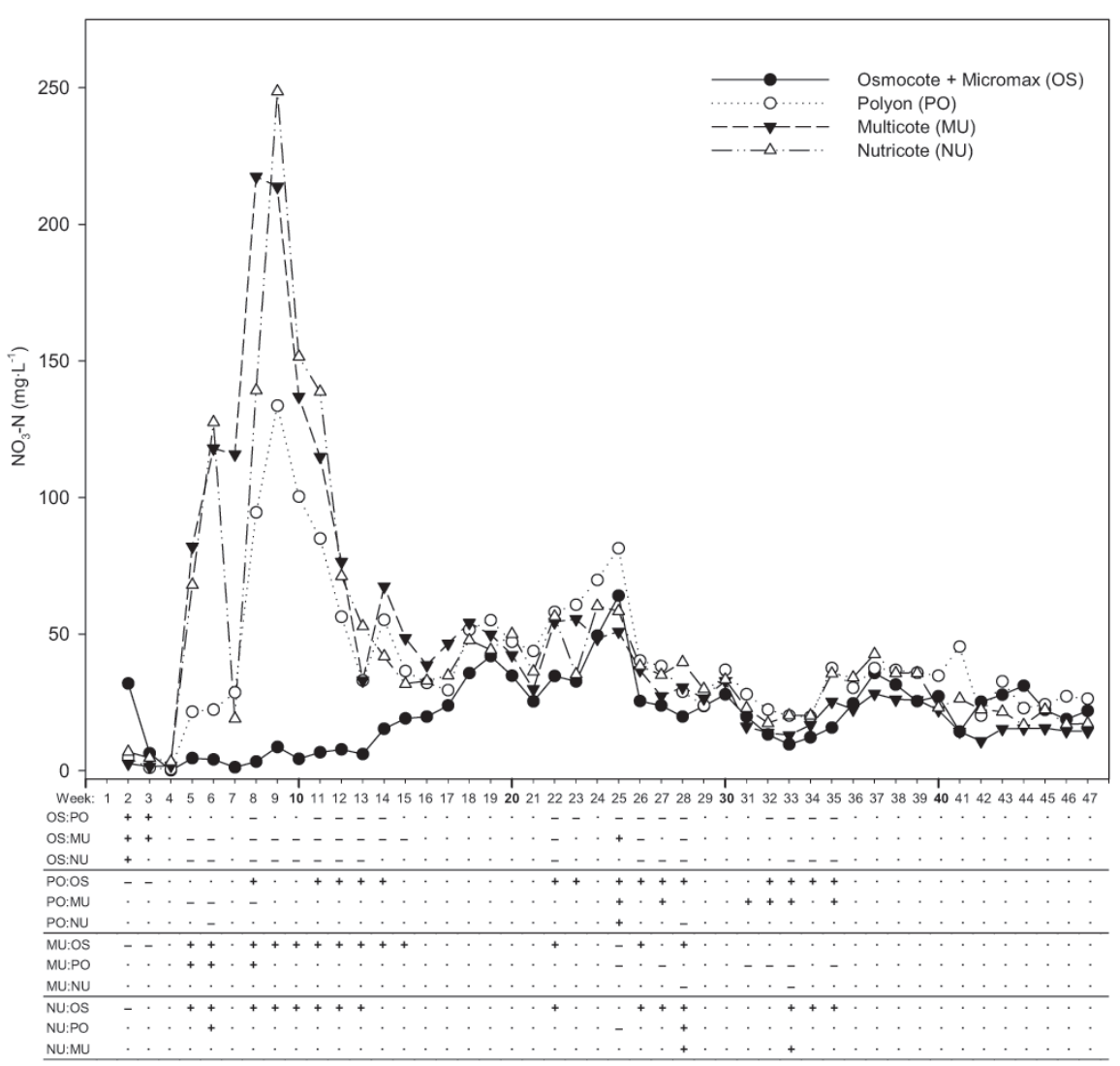

several times during the first 17 weeks of the study. Similar release patterns were observed in other experiments (Broschat, 2005) using 8- to 9-month-release formulations of Osmocote and Nutricote. Broschat (2005) found that 30\% to

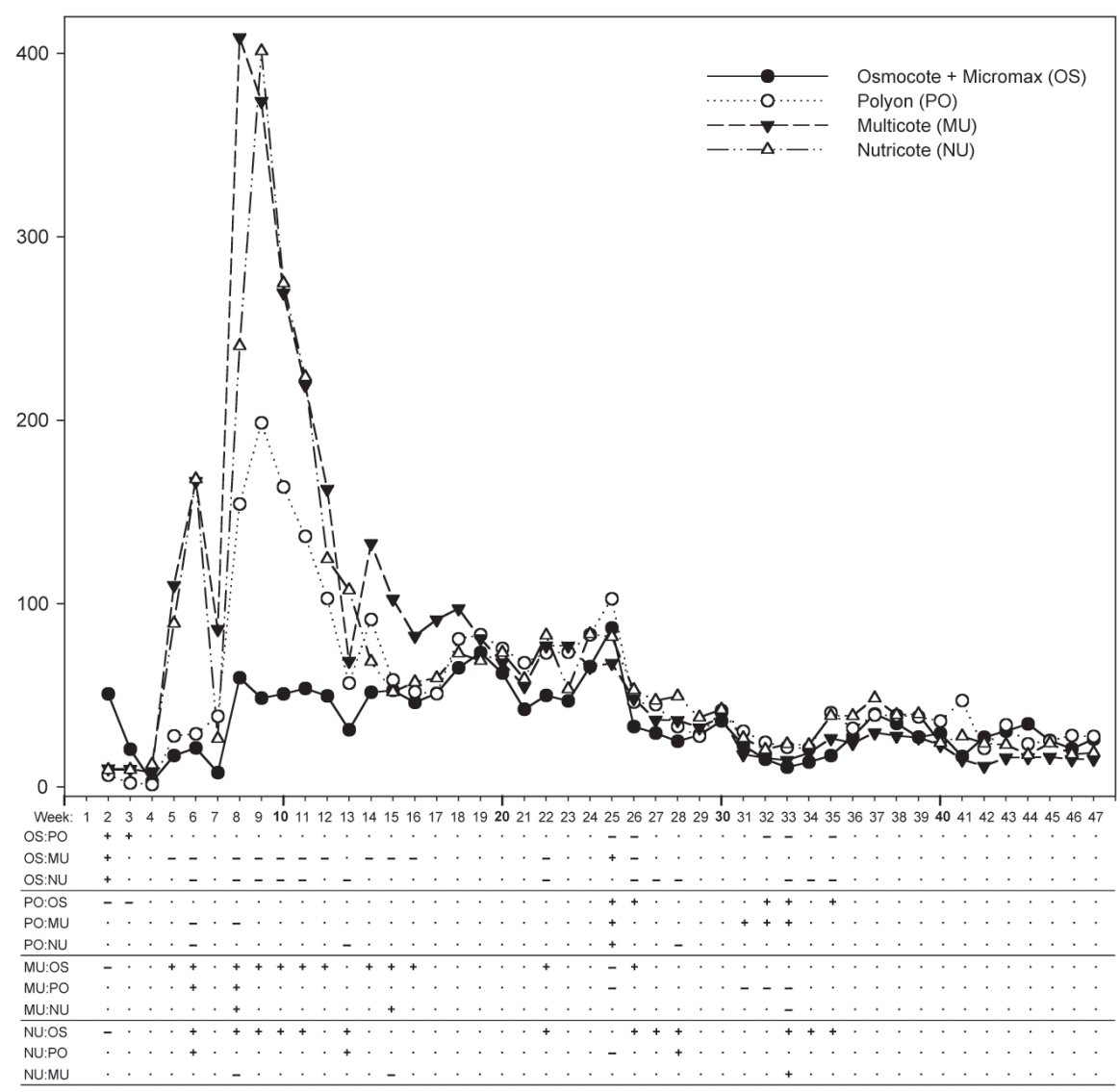

Fig. 5. Concentration of $\mathrm{NO}_{3}^{-} \mathrm{N}\left(\mathrm{mg} \cdot \mathrm{L}^{-1}\right)$ in irrigation leachate collected weekly over a 47-week period (1 Aug. 2001 to 27 June 2002) from a pine bark and peat-based substrate prepared with four controlled-release fertilizers at equal rates of total N. Plotted points (top) represent least squares means for each fertilizer. Significant differences in least squares means for pairs of treatments for each week (bottom) are indicated with the first treatment listed in each pair being greater than $(+)$, less than $(-)$, or not different from $(\bullet)$ the second treatment listed in each pair according to Tukey's test $(P \leq 0.10)$. One-gallon containers containing substrate without plants were located in a controlled-environment greenhouse during the experiment and irrigated with drip emitters using municipal tap water.

(2005), the percentage of $\mathrm{NH}_{4}^{+} \mathrm{N}$ from the $\mathrm{CRF}$ recovered in the leachates in the present study were lower, which is probably due to the binding of $\mathrm{NH}_{4}^{+} \mathrm{N}$ to organic matter of the container substrate (Foster et al., 1983; Thomas and Perry, 1980). The decrease in $\mathrm{NH}_{4}^{+} \mathrm{N}$ concentrations of leachates during the later stages of the present study may be partly accounted for by lower quantities of $\mathrm{NH}_{4}^{+} \mathrm{N}$ that remained in the prills (Broschat, 2005). In addition, there was probably nitrification of $\mathrm{NH}_{4}^{+}$to $\mathrm{NO}_{3}^{-}$in the present study. In studies associated with nitrification of $\mathrm{NH}_{4}^{+}$, it was determined that most of the $\mathrm{NH}_{4}^{+}$is converted to $\mathrm{NO}_{3}^{-}$, with a slower rate of nitrification when soil pH was lower (Dancer et al., 1973; Niemiera and Wright, 1986) or when substrate temperatures exceed $46{ }^{\circ} \mathrm{C}$ (Walden and Wright, 1995). In a diurnal study (Husby et al., 2003), $\mathrm{NH}_{4}^{+} \mathrm{N}$ release was closely associated with temperature, with greater release of $\mathrm{NH}_{4}^{+}$from Osmocote compared to Nutricote or Polyon at high temperatures $\left(>35^{\circ} \mathrm{C}\right)$, but lower release rates at low temperatures $(<35$ ${ }^{\circ} \mathrm{C}$ ). In the present study, air temperatures were seldom above $35^{\circ} \mathrm{C}$, which may explain the fairly level $\mathrm{NH}_{4}^{+} \mathrm{N}$ release patterns.

Federal guidelines do not mention $\mathrm{NH}_{4}^{+} \mathrm{N}$ concentration, but do state that concentrations of unionized ammonia, expressed as $\mathrm{NH}_{3}$, should not exceed $0.02 \mathrm{mg} \cdot \mathrm{L}^{-1}$ for freshwater aquatic life (U.S. EPA, 1976). Based on other research (Thurston et al., 1974), this would mean that total ammonia $\left(\mathrm{NH}_{4}^{+}+\mathrm{NH}_{3}\right)$ concentration, which was measured in the present

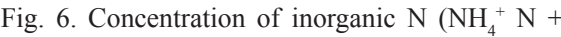
$\left.\mathrm{NO}_{3}{ }^{-} \mathrm{N}\right)\left(\mathrm{mg} \cdot \mathrm{L}^{-1}\right)$ in irrigation leachate collected weekly over a 47-week period (1 Aug. 2001 to 27 June 2002) from a pine bark and peat-based substrate prepared with four controlled-release fertilizers at equal rates of total N. Plotted points (top) represent least squares means for each fertilizer. Significant differences in least squares means for pairs of treatments for each week (bottom) are indicated with the first treatment listed in each pair being greater than $(+)$, less than $(-)$, or not different from $(\bullet)$ the second treatment listed in each pair according to Tukey's test $(P \leq 0.10)$. One-gallon containers containing substrate without plants were located in a controlled-environment greenhouse during the experiment and irrigated with drip emitters using municipal tap water. 


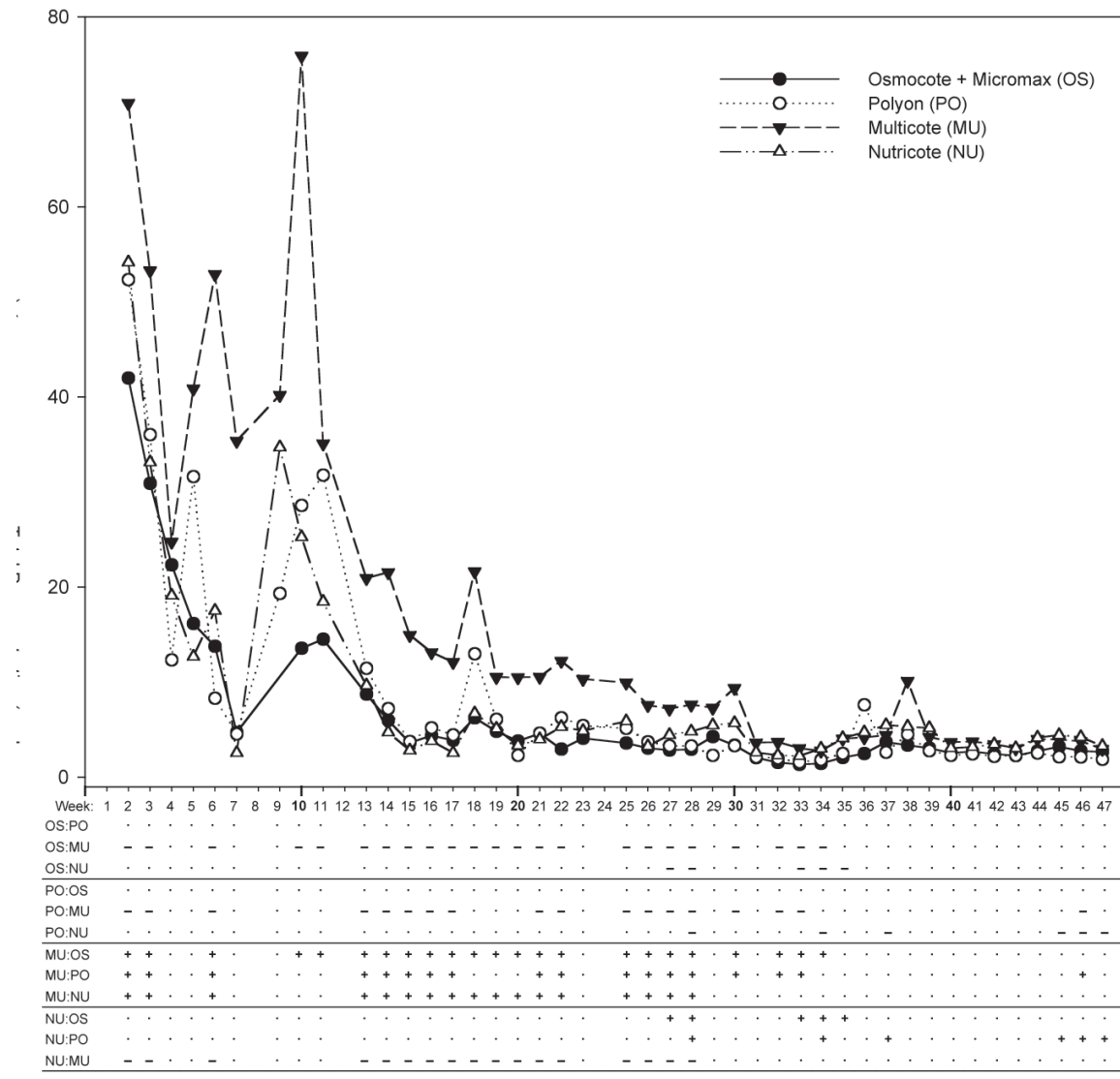

study, would have to be in the range of 16 to $160 \mathrm{mg} \cdot \mathrm{L}^{-1}$ for a solution $\mathrm{pH}$ range of 7.0 to 6.0 , but is also dependent on solution temperature. Given these criteria, it is likely that $\mathrm{NH}_{3}$

itions could have exceeded federal the experiment.

Nitrate nitrogen concentration. In all

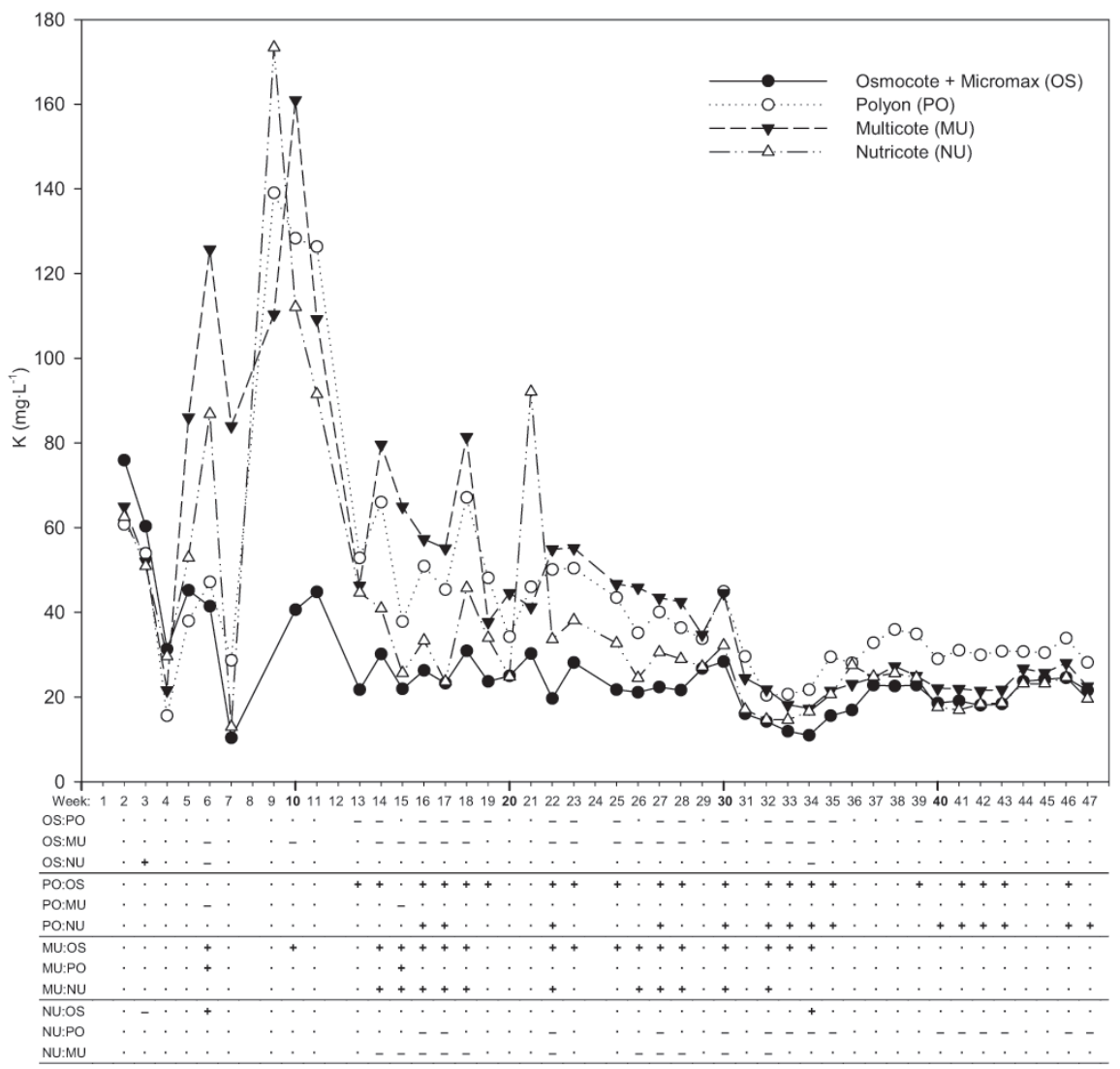

Fig. 7. Concentration of total $\mathrm{P}\left(\mathrm{mg} \cdot \mathrm{L}^{-1}\right)$ in irrigation leachate collected weekly over a 47 -week period (1 Aug. 2001 to 27 June 2002) from a pine bark and peat-based substrate prepared with four controlled-release fertilizers at equal rates of total N. Plotted points (top) represent least squares means for each fertilizer. Significant differences in least squares means for pairs of treatments for each week (bottom) are indicated with the first treatment listed in each pair being greater than $(+)$, less than $(-)$, or not different from $(\bullet)$ the second treatment listed in each pair according to Tukey's test $(P \leq 0.10)$. One-gallon containers containing substrate without plants were located in a controlled-environment greenhouse during the experiment and irrigated with drip emitters using municipal tap water.

fertilizer treatments, $\mathrm{NO}_{3}^{-} \mathrm{N}$ concentrations were below $10 \mathrm{mg} \cdot \mathrm{L}^{-1}$ during the first 4 weeks of the study, with the exception of week 2, when leachate from the Osmocote treatment averaged $32 \mathrm{mg} \cdot \mathrm{L}^{-1}$ (Fig. 5). From week 4 to week $9, \mathrm{NO}_{3}^{-} \mathrm{N}$ concentrations increased to over $100 \mathrm{mg} \cdot \mathrm{L}^{-1}$ for all treatments except Osmocote. From week 10 to the end of the study, $\mathrm{NO}_{3}^{-} \mathrm{N}$ concentration decreased and leveled off to about $30 \mathrm{mg} \cdot \mathrm{L}^{-1}$ for leachates from treatments containing Nutricote, Polyon, or Multicote. However, for Osmocote, leachate $\mathrm{NO}_{3}^{-} \mathrm{N}$ concentrations gradually increased to about $50 \mathrm{mg} \cdot \mathrm{L}^{-1}$ and then decreased to about 30 $\mathrm{mg} \cdot \mathrm{L}^{-1}$ during the remaining 20 -week period. Of the fertilizers tested, Osmocote appeared to produce the most stable release pattern of $\mathrm{NO}_{3}^{-} \mathrm{N}$. During one-third of the weeks of the study, $\mathrm{NO}_{3}^{-} \mathrm{N}$ concentrations were lower for Osmocote compared with the leachate collected from the other fertilizer types. Similarly, the $\mathrm{NO}_{3}^{-} \mathrm{N}$ concentration in leachates collected from the Polyon treatment was significantly lower than for Multicote 6 weeks out of ten during weeks 25 through 35 . The release pattern of $\mathrm{NO}_{3}^{-}$in leachates from Osmocote and Nutricote treatments are similar to the release characteristics determined by others (Broschat, 2005; Prasad and Woods, 1971), except that, on a weekly basis, the data from the present study indicated that Osmocote may have a lower, but more stable, $\mathrm{NO}_{3}{ }^{-}$release pattern from the prills compared to Nutricote. In general, the elevated concentrations of $\mathrm{NO}_{3}^{-}$relative to $\mathrm{NH}_{4}^{+}$, especially during the later half of the study, are probably associated with the nitrification of $\mathrm{NH}_{4}^{+}$in addition to the release of $\mathrm{NO}_{3}{ }^{-}$from the fertilizer prills. Other stud-

Fig. 8. Concentration of $\mathrm{K}\left(\mathrm{mg} \cdot \mathrm{L}^{-1}\right)$ in irrigation leachate collected weekly over a 47 -week period (1 Aug. 2001 to 27 June 2002) from a pine bark and peat-based substrate prepared with four controlled-release fertilizers at equal rates of total N. Plotted points (top) represent least squares means for each fertilizer. Significant differences in least squares means for pairs of treatments for each week (bottom) are indicated with the first treatment listed in each pair being greater than $(+)$, less than $(-)$, or not different from $(\bullet)$ the second treatment listed in each pair according to Tukey's test $(P \leq 0.10)$. One-gallon containers containing substrate without plants were located in a controlled-environment greenhouse during the experiment and irrigated with drip emitters using municipal tap water. 
ies have demonstrated significant nitrification of $\mathrm{NH}_{4}^{+}$in soils and substrates of acidic to neutral pH (Dancer et al., 1973; Niemiera and Wright, 1986).

Based on federal guidelines of a maximum of $10 \mathrm{mg} \cdot \mathrm{L}^{-1}$ of $\mathrm{NO}_{3}^{-} \mathrm{N}$ for domestic water use (U.S. EPA, 1976), $\mathrm{NO}_{3}^{-} \mathrm{N}$ concentrations exceeded permissible levels during most of the experiment. However, if plants had been included in the present study, the likelihood of $\mathrm{NO}_{3}^{-} \mathrm{N}$ leaching in excess of $10 \mathrm{mg} \cdot \mathrm{L}^{-1}$ would probably only have existed during the first 12 weeks of the study when total concentrations of $\mathrm{NO}_{3}^{-} \mathrm{N}$ were above $100 \mathrm{mg} \cdot \mathrm{L}^{-1}$. The only fertilizer product in exception to this was Osmocote, which had relatively low $\mathrm{NO}_{3}^{-} \mathrm{N}$ concentrations during the entire period of the study.

Total inorganic N concentrations. Release characteristics as indicated by total inorganic-N concentrations (ammonium + nitrate) showed significant release of $\mathrm{N}$ during the first 9 weeks of the study, then a decrease and leveling off period during the remaining 36 weeks for Polyon, Nutricote, and Multicote (Fig. 6). The exception to this pattern was Osmocote, which had more consistent leachate inorganic $\mathrm{N}$ concentrations between 30 and $50 \mathrm{mg} \cdot \mathrm{L}^{-1}$ throughout the entire experimental period. The pattern of high then low $\mathrm{N}$ release during the beginning and end of the experiment, respectively, are similar to other studies (Huett, 1997b; Huett and Gogel, 2000; Prasad and Woods, 1971; Patel and Sharma, 1977). The initial lag in $\mathrm{N}$ appearance in leachate in the present study may be partially due to chemical and biological immobilization of $\mathrm{N}$ in the organic substrate, which has been documented by others (Foster et al., 1983; Gartner et al., 1971; Handreck and Bunker, 1996; Thomas and Perry, 1980). In addition, concentrations of $\mathrm{NH}_{4}^{+}$relative to $\mathrm{NO}_{3}^{-}$were similar during the first half of the study, but $\mathrm{NO}_{3}^{-}$was the predominant inorganic $\mathrm{N}$ form during the later half of the study, regardless of fertilizer type. This phenomenon is probably associated with the nitrification of $\mathrm{NH}_{4}^{+}$, as demonstrated in other studies (Dancer et al., 1973) and possibly the faster release rate of $\mathrm{NH}_{4}^{+} \mathrm{N}$ from the prills, relative to $\mathrm{NO}_{3}$, as measured by Broschat (2005). In shorter-term studies (6 months), $\mathrm{NO}_{3}^{-}$was the predominant $\mathrm{N}$ form during the entire experimental period (Cabrera, 1997). Regardless of fertilizer type, the present study did not detect any significant correlation of inorganic $\mathrm{N}$ release with air temperatures. These results differ from studies conducted by Cabrera (1997) and Handreck (1997), where N release characteristics of Osmocote, Nutricote, and Polyon were closely associated with temperature. However, the experiments conducted by Cabrera lasted 9 months, during which time temperatures slowly increased then decreased, and the studies conducted by Handreck were in a temperature-controlled $\left(21^{\circ} \mathrm{C}\right)$ laboratory. In the present study, temperatures fluctuated, with relatively high temperatures during the first 2 months, then decreasing during the winter, and then increasing again during the following spring.

Total phosphorus concentrations. Since fertilizer additions were normalized for $\mathrm{N}$ content, total $\mathrm{P}$ content added differed among fertilizer treatments, with an average $P$ content of $0.40 \mathrm{~g} /$ container for Polyon, Nutricote, and Multicote, but 50\% less for Osmocote ( $0.22 \mathrm{~g} /$ container). Phosphorus concentrations in leachates of all treatments fluctuated throughout the study, but were higher (15 to $>60 \mathrm{mg} \cdot \mathrm{L}^{-1}$ ) during the first 10 weeks compared to the last 27 weeks of the study, when concentrations averaged below $10 \mathrm{mg} \cdot \mathrm{L}^{-1}$ (Fig. 7). The pattern of high then low $P$ release in the present study is similar to other studies with Osmocote, Nutricote, and Polyon (Huett, 1997b; Huett and Gogel, 2000). When comparing treatments, Multicote tended to produce the highest $P$ concentrations in leachates compared to the other fertilizers types, primarily during the first 37 weeks. For the most part, total P concentrations of other treatments were somewhat similar throughout the study. In another experiment(Broschat, 2005), release of P from Osmocote prills during the first 5 months was significantly greater than that measured from Nutricote; however, by month 7, differences in release were not significant. In shorter-term studies (10 weeks), there were no differences in $\mathrm{P}$ release rates between Osmocote and $\mathrm{Nu}$ tricote (Huett, 1997b). According to field and container experiments (Flint, 1962; Handreck, 1996; Havis and Baker, 1985a; 1985b; Wright, 1984; Yeager and Wright, 1982), solution P concentrations of about $10 \mathrm{mg} \cdot \mathrm{L}^{-1}$ are required for optimal growth of woody ornamentals. A fraction of this $\mathrm{P}$ is tied in organic substrates, as demonstrated by Handreck(1996). Based on the present study and the experiments of others, it appears that a high release of $\mathrm{P}$ from CRFs may elevate the risk of $P$ leaching during the early parts of the production cycle, but a lower release of P may limit plant growth during the later part of a production cycle.

Regarding P, the U.S. EPA has established a concentration limit of $0.01 \mu \mathrm{g} \cdot \mathrm{L}^{-1}$ for elemental P (U.S. EPA, 1976). There are currently no federal guidelines for ortho-phosphate or total phosphorus. Based on the criterion for total $\mathrm{P}$, the greatest risk of $\mathrm{P}$ leaching would be during the first 20 weeks of the production cycle, especially if any fraction of the total $\mathrm{P}$ determined was elemental in nature.

Total potassium concentrations. Total $\mathrm{K}$ concentrations of leachates from all treatments ranged between 10 and $170 \mathrm{mg} \cdot \mathrm{L}^{-1}$, with higher concentrations during the first 20 weeks of the study compare to the last 27 weeks (Fig. 8). When comparing CRF types, K concentrations in leachates from Osmocote and Nutricote treatments were similar, but both were significantly lower than $\mathrm{K}$ concentrations of leachates collected from containers containing Polyon or Multicote. These differences may be attributed to the amount of $\mathrm{K}$ added, since fertilizer additions were normalized for N. Osmocote and Nutricote contained about $36 \%$ less K than the Polyon and Multicote treatments. While not measured, a portion of the $\mathrm{K}$ released from the prills was probably tied up by the organic fraction, which has been shown to occur with organic substrate (Brown and Pokorny, 1977; Foster et al., 1983). Elevated K release from
CRFs during the early part of the production cycle observed in the present study is similar to other studies (Broschat, 1996, 2005; Huett, 1997b) that compared K release from Osmocote, Nutricote, and Multicote. In other research (Holcomb, 1981) with Osmocote, K release rates were linear throughout the 63-d study period. Even though $\mathrm{K}$ concentrations were elevated in leachates during the first portion of the experiment, there is no concern of $\mathrm{K}$ concentrations exceeding federal recommended guidelines, since no guidelines have been established for $\mathrm{K}$.

\section{Conclusions}

Under unheated greenhouse conditions, the release characteristics of $\mathrm{NH}_{4}^{+}, \mathrm{NO}_{3}^{-}, \mathrm{K}$, and $\mathrm{P}$ from all CRFs tested were elevated during the first half of the study, followed by lower release during the later half of the 11-month period. The nutrient release rates do not appear to be associated with ambient temperature, as high temperatures were moderated with evaporative cooling pads and fans, and there was a general increase in temperature during the spring. Based on the results of this study and data from other long term studies, it appears that nutrient release from all the CRFs tested may be in excess of plant requirements during the first half of the production period (Huett, 1997b; Huett and Gogel, 2000), but may be insufficient during later stages of production (Huett, 1997a), depending on the nutrient demands of the crop being grown and the temperature profiles during production.

Patterns of leachate EC reflect somewhat the leachate concentrations of N, P, and K. These correlations have also been measured by others (Cabrera, 1997; Huett and Morris, 1999; Husby et al., 2003). Leachate EC is probably associated with both nutrient release from CRF and soluble salts leached out of the substrate during the first few weeks of the study.

Differences were noted among fertilizer types, with Multicote often exhibiting a higher nutrient release than the other CRFs tested during the first 20 weeks of the study. However, during the last half of the study, nutrient concentrations in Multicote leachates were sometimes less than the nutrient concentrations recovered from the other fertilizer treatments, suggesting that the high release rates measured for Multicote during the first half of the experiment resulted in a noticeably smaller pool of nutrients available for release during the last half of the study.

From an environmental perspective, risk of water impairment when using the CRFs employed in the present study would be greatest during the first 20 weeks of crop production when $\mathrm{EC}, \mathrm{NH}_{4}^{+} \mathrm{N}, \mathrm{NO}_{3}{ }^{-} \mathrm{N}$, total $\mathrm{P}$, and total $\mathrm{K}$ were elevated. Based on guidelines established by the U.S. EPA (1976), the chemical parameters of $\mathrm{pH}, \mathrm{EC}, \mathrm{NH}_{4}^{+} \mathrm{N}, \mathrm{NO}_{3}^{-} \mathrm{N}$, and $\mathrm{P}$, as observed in the present study, were not within acceptable limits during various time frames throughout the 11-month period. However, concentrations of nutrients in leachates would probably be reduced if plants were present in the containers. For this reason, additional 
research regarding leaching characteristics of CRFs is required, particularly for a typical plant production scenario using woody ornamentals commonly grown in the nursery industry.

\section{Literature Cited}

Argo, W.R. and J.A. Biernbaum. 1997. The effect of root media on root-zone $\mathrm{pH}$, calcium, and magnesium management in containers with impatiens. J. Amer. Soc. Hort. Sci. 122:275-284.

Brown, E.F. and F.A. Pokorny. 1977. Potassium distribution and retention in pine bark and sand media. HortScience 12:343-344.

Broschat, T.K. 1996. Release rates of soluble and controlled-release potassium fertilizers. HortTechnology 6:128-131.

Broschat, T.K. 2005. Rates of ammonium-nitrogen, nitrate-nitrogen, phosphorus, and potassium from two controlled-release fertilizers under different substrate environments. HortTechnology 15:332-335.

Cabrera R.I. 1997. Comparative evaluation of nitrogen release patterns from controlled-release fertilizers by nitrogen leaching analysis. HortScience 32:669-673.

Chen, J., R.C. Beeson, Jr., T.H. Yeager, R.H. Stamps, and L.A. Felter. 2003. Evaluation of captured rainwater and irrigation runoff for greenhouse foliage and bedding plant production. HortScience 38:228-233.

Dancer, W.S., L.A. Peterson, and G. Chesters. 1973. Ammonification and nitrification of $\mathrm{N}$ as influenced by soil $\mathrm{pH}$ and previous $\mathrm{N}$ treatments. Soil. Sci. Soc. Amer. Proc. 37:67-69.

Engelsjord, M.E., O. Fostad, and B.R. Singh. 1997. Effects of temperature on nutrient release from slow-release fertilisers. I. Commercial and experimental products. Nutrient Cycling in Agroecosystems 46:179-187.

Flint, H.L. 1962. Effects of different soil levels and methods of application of phosphorus on growth of selected woody ornamental species in containers. Proc. Amer. Soc. Hort. Sci. 81:552-555.

Foster, W.J., R.D. Wright, M.M. Alley, and T.H. Yeager. 1983. Ammonium adsorption on a pinebark growing medium. J. Amer. Soc. Hort. Sci. 108:548-551.

Franson, M.A. 1985. Method 303A, p. 157-160. In: M.A. Farnson (ed.). Standard methods for the examination of water and wastewater, 16th edition. Amer. Public Health Assn.-Amer. Water Works Assn.-Water Pollution Control Fed. Washington, D.C.

Gandeza, A.T., S. Shoji, and I. Yamada. 1991. Simulation of crop response to polyolefin-coated urea: I. Field dissolution. Soil Sci. Soc. Amer. J. 55:1462-1467.

Gartner, J.B., M.M. Meyer, Jr., and D.C. Saupe. 1971. Hardwood bark as a growing media for container-grown ornamentals. Forest Products J. 21:25-29.

Goertz, H.M. 1993. Controlled release technology, p. 251-274. In: Kirk-Othmer(ed.). Encyclopedia of chemical technology. vol. 7. 4th ed. Wiley \& Sons, New York.

Handreck, K.A. 1996. Phosphorus immobilization in wood waste-based potting media. Commun. Soil Sci. Plant Anal. 27:2295-2314.

Handreck, K. 1997. Controlled release fertilisers. Measuring nutrient release rates. Austral. Hort. 95(10):51-53

Handreck, K. and K. Bunker. 1996. Fertilisers and hot weather. Austral. Hort. 94(8):83-85.

Havis, J.R. and J.H. Baker. 1985a. Phosphorus availability in peat-sand media fertilized with several phosphorus sources. J. Environ. Hort. 3:153-155.

Havis, J.R. and J.H. Baker. 1985b. Phosphorus requirement of Rhododendron 'Victor' and Cotoneaster adpressa praecox grown in a perlite-peat medium. J. Environ. Hort. 3:63-64.

Holcomb, E.J. 1981. Potassium release from selected slow-release fertilizers. Commun. Soil Sci. Plant Anal. 12:1303-1310.

Huett, D.O. 1997a. Fertiliser use efficiency by containerized nursery plants. I. Plant growth and nutrient uptake. Austral. J. Agr. Res. 48:251-258.

Huett, D.O. 1997b. Fertiliser use efficiency by containerized nursery plants. II. Nutrient leaching. Austral. J. Agr. Res. 48:259-265.

Huett, D.O. and B.J. Gogel. 2000. Longevities and nitrogen, phosphorus, and potassium release patterns of polymer-coated controlled-release fertilizers at $30^{\circ} \mathrm{C}$ and $40^{\circ} \mathrm{C}$. Commun. Soil Sci. Plant Anal. 31:959-973.

Huett, D.O. and S.C. Morris. 1999. Fertiliser use efficiency by containerized nursery plants. 3 . Effect of heavy leaching and damaged fertilizer prills on plant growth, nutrient uptake, and nutrient loss. Austral. J. Agr. Res. 50:217-222.

Husby, C.E., A.X. Niemiera, J.R. Harris, and R.D. Wright. 2003. Influence of diurnal temperature on nutrient release patterns of three polymer-coated fertilizers. HortScience 38:387-389.

Ingram, D.L. 1981. Characterization of temperature fluctuations and woody plant growth in white poly bags and conventional black containers. HortScience 16:762-763.

Ivy, R.L., T.E. Bilderback and S.L. Warren. 2002. Date of potting and fertilization affects plant growth, mineral nutrient content, and substrate electrical conductivity. J. Environ. Hort. 20:104-109.

Kochba, M., S. Gambash, and Y. Avnimelech. 1990. Studies on slow release fertilizers. I. Effect of temperature, soil moisture and water vapor pressure. Soil Sci. 149:339-343.

Lamont, G.P., R.J. Worrall, and M.A. O’Connell.
1987. The effects of temperature and time on the solubility of resin-coated controlled-release fertilizer under laboratory and field conditions. Scientia Hort. 32:265-273.

Lang, H.J. 1996. Growing media testing and interpretation, p.123-139. In:D.W. Reed(ed.). Water, media, and nutrition for greenhouse crops. Ball, Batavia, Ill.

Lunt, O.R. and J.J. Oertli. 1962. Controlled release of fertilizer minerals by incapsulating membranes: II. Efficiency of recovery, influence of soil moisture, mode of application, and other considerations related to use. Soil Sci. Soc. Amer. Proc. 26:584-587.

Niemiera, A.X. and R.D. Wright. 1986. The influence of nitrification on the medium solution and growth of holly, azalea, and juniper in a pine bark medium. J. Amer. Soc. Hort. Sci. 11:708-712.

Oertli, J.J. and O.R. Lunt. 1962. Controlled release of fertilizer minerals by incapsulating membranes: I. Factors influencing the rate of release. Soil Sci. Soc. Amer. Proc. 26:579-583.

Patel, A.J. and G.C. Sharma. 1977. Nitrogen release characteristics of controlled-release fertilizers during a four month soil incubation. J. Amer. Soc. Hort. Sci. 102:364-367.

Prasad, M. and M.J. Woods. 1971. Release characteristics of nitrogen fertilizer in peat and sand. J. Agr. Food Chem. 19:96-98.

Rathier, T.M. and C.R. Frink. 1989. Nitrate in runoff water from container grown juniper and Alberta spruce under different irrigation and $\mathrm{N}$ fertilization regimes. J. Environ. Hort. 7:32-35.

Sweeney, R.A. 1989. Generic combustion method for determination of crude protein in feeds: Collaborative study. J. Assn. Offic. Anal. Chem. 72:770-774.

Thomas, S. and F.B. Perry, Jr. 1980. Ammonium nitrogen accumulation and leaching from an all pine bark medium. HortScience 15:824-825.

Thurston, R.V., R.C. Russo, and K. Emerson. 1974. Aqueous ammonia equilibrium calculations. Fisheries Bioassay Lab. Tech. Rpt. No. 74-1, Mont. State Univ., Bozeman, Mont.

U.S. Environmental Protection Agency. 1976. Quality Criteria for Water. EPA Document No. 440/9-76-023. U.S. Environ. ProtectionAgency, Wash., D.C

Walden, R.F. and R.D. Wright. 1995. Interactions of high temperature and exposure time influence nitrification in a pine bark medium. HortScience 30:1026-1028.

Wright, R.D. 1984. The pour-through method: A quick and easy way to determine a medium's nutrient availability. Amer. Nurseryman 160(3):109-111.

Yeager, T.H. and R.D. Wright. 1982. Phosphorus requirement of Ilex crenata Thumb. cv. Helleri grown in pine bark medium. J. Amer. Soc. Hort. Sci. 107:558-562. 